\title{
Legal basis and prospects of development of mediation in the republic of Uzbekistan
}

\section{Sirojiddin ABDUVOITOV ${ }^{1}$ \\ University of World Economy and Diplomacy}

\begin{tabular}{l} 
ARTICLE INFO \\
\hline Article history: \\
Received September 2020 \\
Received in revised form 15 \\
September 2020 \\
Accepted 25 September \\
2020 \\
Available online \\
1 October 2020
\end{tabular}

Keywords:

Mediation

Agreement of the parties

Views and principles of

mediation

Legal dispute resolution

Mediator

Alternative form of dispute

resolution.

\begin{abstract}
In the article, the law of the Republic of Uzbekistan "on mediation" has been studied in order to create the necessary legal ground for the settlement of the dispute in the legal system of developed foreign countries without pre-trial, that is, the mediation process, which is aimed at the solution by alternative means, plays an important role in our country.

This is an open access article under the Attribution 4.0 International (CC BY 4.0) license (https://creativecommons.org/licenses/by/4.0/deed.ru)
\end{abstract}

\section{O’zbekiston respublikasida mediatsiyaning huquqiy asoslari va rivojlanish istiqbollari}

\author{
Kalit so'zlar: \\ Mediatsiya \\ Taraflarning kelishuvi \\ Mediatsiya ko'rinishlari va \\ prinsiplari \\ Huquqiy nizolarni hal qilish \\ mediator, \\ Nizolarning hal qilishning \\ muqobil shakli..
}

\begin{abstract}
ANNOTATSIYA
Maqolada hozirgi kunda rivojlangan xorijiy davlatlar huquqiy tizimida nizoni sudgacha olib bormasdan, muqobil yo'l bilan hal qilishga qaratilgan mediatsiya ya'ni yarashtiruv jarayoni sifatidagi o'rni ochib berilgan va umuman mediatsiya tushunchasi va tamolillari va uning ko'rinishlari va bu borada O’zbekiston Respublikasining "Mediatsiya to'g'risida"gi qonuni o'rganilib chiqilgan.
\end{abstract}

\footnotetext{
${ }^{1}$ LLM student in International business law, University of World Economy and Diplomacy, Tashkent, Uzbekistan email: sirojiddinabduvoitov@gmail.com
} 


\section{Правовые основы и перспективы развития медиации в Республике Узбекистан}

\author{
Ключевые слова: \\ Медиация \\ Соглашение сторон \\ Принципы медиации \\ Разрешение правовых \\ споров \\ Посредник \\ Альтернативная форма \\ разрешения споров.
}

\begin{abstract}
АННОТАЦИЯ
В статье изучены понятие и принципы медиации в целом и ее проявления, а также Закон Республики Узбекистан “0 медиации". В связи с тем, что медиация, направленная на альтернативное решение спора, то есть процесс примирения, создает необходимую правовую основу, регулирующую сферу реализации действительно рыночных механизмов и в нашей стране.
\end{abstract}

\section{INTRODUCTION.}

As the relations based on the market economy are developing rapidly in our country, it is inevitable that there will be various conflicts between the entities. The parties will have to choose the traditional way for the purpose of finding a solution to the dispute, that is, apply to the court.

Nowadays, in the legal system of developed foreign countries, the process of mediation - reconciliation is of particular importance, aimed at an alternative solution of the dispute without pre-trial proceedings. The country also requires the creation of the necessary legal framework regulating the sphere of implementation of truly market forces.

The law "on Mediation"[1], implemented into practice by the signature of the president of the Republic of Uzbekistan, has brought into circulation new concepts of media, as well as legal regulation of another sphere of public life. At the same time, Uzbekistan is at the initial stage of using media as an alternative method of dispute resolution. When thinking about this law, which came into force in 2019 Year 1 January, first of all it is necessary to touch on the lexical meaning of the word "mediation".

Mediation (from the Latin word "mediare" - mediation) [2, p. 253] is a procedure for reconciling conflicting parties by entering into voluntary negotiations with the participation of the mediator in order to reach an agreement for the purpose of mutual agreement and settlement of disputes [3 p. 8]. Therefore, it is used in international terminology and is translated as "mediation". Therefore, in the legal literature, the concepts of mediation and mediation are directly synonymous. In addition, according to the law "on Mediation", mediation - a method of settling a dispute with the assistance of a mediator on the basis of the voluntary consent of the parties in order to reach a mutually acceptable solution. If we look at the history of the development of media, we can see that S. Shamlikashvili believes that the media goes back to ancient times with its main idea. He noted that from the moment of the appearance of disputes, mediation also began to form slowly. In addition, an independent third party (mediator), even if he does not have the right to make a decision, will help the parties in the dispute to resolve the dispute independently [4 p. 14]. N.Y. Alexander's research work concludes that the forms of mediations began to appear in Asia, Africa, the Pacific, ancient Greece and Rome [5 p. 2-3].

In his research, Roebak gives an idea of the emergence of media in Ancient Greece [6 p. 66]. Also during the research of Roebak, homer analyzes the works of Greek philosophers such as Geredot, Gesiod, Plato, Aristotle, Demosfen, and determines the 
conditions for the emergence of a system of mediations in Ancient Greece and comes to the following conclusions:

- mediation is a key element. No matter how formal the process was, the mediation was first tested and the decision to mediate was given priority. But with the exception of certain types of litigation, of course;

- Arbitrators often offer such opportunities to the defeated party in order to mitigate their defeat, even if little, in the end, that the parties would have a favorable opportunity to overcome their disagreements;

- Mediation and arbitration are an additional method of dispute resolution in all of ancient Greece that has always come to use the methods of the ADR and these methods have in turn evolved together to complement and bleach one another;

- In ancient Greece, we can conclude that mediation and arbitration as a method of ADR were so important and necessary, and the work done in this regard, it is necessary to emphasize that in the ancient Greek world it is of social importance in a peculiar way [7 p. 86-87].

Mediation is a new method of dispute resolution for the Republic of Uzbekistan. In the USA, Western Europe and many countries, dispute resolution using this method is widely used in practice. For example, as an alternative way of resolving disputes in the US, mediation has 2 main directions: 1 ) in the current judicial system (public sphere) and 2) in the field of private legal regulation is developing [8 p. 15]. We can also witness that in the US, many alternative methods of resolving media-like disputes such as "mediationarbitration", "Mini-Court", "evaluation of experts", and others have been developed [9]. Mediation is recognized in many countries of the world as the most optimal way of peaceful settlement of disputes.

In this regard, it is also natural to ask some questions: How does the adoption of this legal document serve the legitimate rights and interests of our people? What do mediations appear in our country? What are its main principles and advantages? What factors influence the application of mediation in the daily life of the society? Are the conditions sufficient for the development of mediation?

Today, in Uzbekistan, mediation-like reconciliation processes are used in the resolution of various conflicts. In particular, the parties to the conflict by the self-governing bodies of citizens, in particular, disputes between troops, the activities of reconciling family disputes can also be seen as a form of media. Earlier in our society, the heads of the neighborhood performed the task of resolving disputes between neighbors, family members, a couple, that is, a mediator.

The law also clearly defines the scope of its action. According to him, the law applies to relations involving the use of mediation in disputes arising from civil law relations, including in connection with business activities, as well as individual labor disputes and disputes arising from family law relations.

\section{BASIC PRINCIPLES OF MEDIATION}

Article 5 of the law establishes that mediation is conducted on the basis of the principles of confidentiality, voluntariness, cooperation and equality of the parties, independence and impartiality of the mediator. At the same time, special attention was paid to the issues of ensuring their equality in the process of mediation, and specific norms were introduced in this regard. Another important aspect should be paid attention, that is, 
ensuring the objectivity of the mediator in the implementation of mediation procedures also affects the process of resolving the dispute. The law strictly stated that interference in the activities of the mediator in the implementation of mediation procedures should not be allowed in some way. At the same time, it was envisaged that the mediator should be a position, conduct mediatory procedures in the interests of the parties and ensure their equal participation in the media, create the necessary conditions for the parties to fulfill their obligations and exercise the rights granted to them, in the event that there are circumstances that hinder the independence and impartiality of the In addition, the law clearly defines the rights and obligations of the participants in the mediation as well. The Mediator serves as an informal participant in the process, his recommendations and decisions are not binding on the parties involved in the conflict [10 p. 9]. In addition, the mediator may not be interested in the defeat of the parties [11 p. 4]. The main thing is that it should bring mutual reconciliation of the parties [12 p. 93].

Mediation has the following important principles:

* Voluntariness, that is, mediation is used in the case of mutual voluntary will of the parties, expressed in an agreement on the use of mediation.

Parties to a mediation have the right to refuse to use mediation at any stage.

The parties are free to choose questions to discuss a mutually acceptable agreement. Forced reconciliation during a mediation procedure is prohibited;

* Confidentially. Participants in mediation are not entitled to disclose information that became known to them during mediation without the written consent of the mediation party that provided this information to its successor or representative.

The participants of mediation cannot be interrogated as a witness about the circumstances that became known to them during the mediation, and information from them cannot be demanded concerning the mediation, except as required by law;

* Principle of independence and impartiality of the mediator. When conducting a mediation procedure, the mediator is independent. Any intervention in the activities of the mediator in the mediation procedure is unacceptable.

The mediator must be impartial, conduct the mediation procedure in the interests of the parties and ensure their equal participation in mediation, create the necessary conditions for the parties to fulfill their obligations and exercise the rights granted to them. If there are circumstances that impede the independence and impartiality of the mediator, he must refuse to conduct the mediation procedure.

The Mediator serves as an informal participant in the process, his recommendations and decisions are not binding on the parties involved in the conflict. In addition, the mediator may not be interested in the defeat of the parties. The main thing is that it should bring mutual reconciliation of the parties;

* Principle of cooperation and equality of the parties. The mediation procedure should be conducted with the exception of unilateral influence on the conditions of the mediation agreement.

The mediation procedure is conducted on the basis of the cooperation of the parties in order to achieve a mutually acceptable solution to the dispute.

The parties to mediation enjoy equal rights when choosing a mediator, the procedure for conducting the mediation procedure, their position in the mediation procedure, ways and means of defending it, when receiving information, in assessing the 
mutual acceptability of the terms of the mediation agreement and bear equal responsibilities.

Mediation takes much less time than the judicial process, the legal validity of the decision, in contrast to the resolution of the conflict situation in the judicial procedure, the degree of achievement of the result as a result of mediation depends not only on the work of state bodies, but also on the conflicting parties.

In any case, mediation is not an activity limited to certain template frames, but only a personal affair. In certain cases, the personal experience of the media is generally unacceptable: the experience gained by the participants of the mediation procedure is not used in relation to other and similar situations.

At present, the activities of mediators in Uzbekistan can be carried out on a professional or unprofessional basis. On January 31, 2019, the order of the Minister of Justice of the Republic of Uzbekistan № 54 "on approval of the program of training mediators" [13] was adopted, the program of training mediators was approved by this order, special training courses on the program of training mediators were established by the Center for professional development of lawyers under the Ministry of Justice. Of course, in this training course, a person engaged in mediatory activities on an unprofessional basis can also study. On the basis of the program established over the past period, 22 mediators will receive a certificate of professional mediator upon completion of the training courses and carry out the mediator activity after being included in the Register of professional mediators of the Ministry of Justice [14]. This will later allow him to engage in this activity on a professional basis and will be the basis for inclusion in the list of professional mediators. According to the law, the persons cannot be the mediator:

- authorized to perform public functions or equivalent to it, with the exception of notaries;

- in respect of which there is a court decision that has entered into legal force on recognizing it as partially capable or incapable;

- having outstanding conviction or conviction;

- in respect of which the prosecution is carried out.

- The activity of the mediator is not an entrepreneurial activity.

Mediation is used on the basis of the desire of the parties. It can be applied in an extra - judicial procedure, in the process of viewing the dispute in a judicial procedure, before the court enters a separate room-a consultation room for the adoption of a judicial document. The agreement on the use of media is concluded in writing in the form of a condition that is part of it in the contract or in the form of a separate agreement. The agreement should contain a rule that all or certain disputes arising or likely to arise between the parties should be resolved by the implementation of the procedure of the media.

Direct intervention of the state body during the implementation of the procedure is prohibited. In the course of the judicial proceedings, the mediative agreement reached by the parties during the implementation of the mediation procedure at the time of viewing the dispute in the competent state body shall be immediately sent to the same court or to the competent state body in which case the relevant case is standing in the jurisdiction of the court or competent state In case of settlement of the dispute by agreement in the order of mediation, the state fee paid shall be refunded. 


\section{CONCLUSION}

In conclusion, like any innovation, after the mediation Institute has been tested in practice, its positive aspect, its advantages are clearly manifested. The adoption of a law concerning the court-connected mediation with the above-mentioned provisions would create the necessary legal basis for the legal regulation of the mediation procedure in the Republic of Uzbekistan. Uzbek model of mediation should be based on the legal culture of the state. After the implementation the state should promote this procedure among the legal councils and disputants. Moreover, in order to make a mediation procedure a popular dispute resolution procedure the state should provide some privileges for the parties. I think that this law plays an important role in the peaceful settlement of civil, labor and economic, commercial disputes between individuals and legal entities and in ensuring the legal rights and interests of the parties.

\section{References;}

1. O'zbekiston Respublikasining 2018 yil 3 iyuldagi O'RQ-482-sonli qonuni

2. English-Russian terms on civil law and law of civil procedure / Compiled by S.D. Oskina. - Omsk, 2003. - $253 \mathrm{p}$

3. Медиация в нотариальной практике (Альтернативные способы разрешения конфликтов) Wolters Kluwer Russia, 2005, ст. 8

4. Шамликашвили Ц.А. Медиация - современный метод внесудебного разрешения споров. М.: МЦУПК, 2006. - 14 с.

5. N. Alexander "Global Trends in Mediation: Riding the Third Wave' in N. Alexander (ed.), Global Trends in Mediation (Netherlands: Kluwer Law International BV, 2006), p. 23.

6. Roebuck D. 'Best to Reconcile': Mediation and Arbitration in the Ancient Greek World' Arbitration (2002) 66-pp.275-87

7. Roebuck D. 'Best to Reconcile': Mediation and Arbitration in the Ancient Greek World' Arbitration (2002) p. 86-87

8. Хесль Г. Посредничество в разрешении конфликтов. Теория и технология. СПб. 2004 г. - С. 15.

9. Штепан,П. Альтернативные способы разрешения споров. http://law.edu.ru/doc/document.asp?docID=1129449

10. Ш.М.Масадиков Проблемы правового регулирования медиации/ Монография. - Т., 2014.

11. Леннуар Н.Н. Альтернативное разрешение споров: переговоры и медиация: Учеб.-метод. пособие. - СПб.: Изд-во Санкт-Петербургского института права имени Принца П.Г. Ольденбургского, 2004, ст. 9

12. Ivan Bernier \& Nathalie Latulippe, Conciliation as a Dispute Resolution Method in the Cultural Sector, The International Convention on The Protection and Promotion of The Diversity of Cultural Expressions, p.4.

13. Thomas D. Cavenagh \& Lucille M. Ponte, Alternative Dispute Resolution in Business, West Educational Publishing Company, 1991, p. 93.

14. https://teletype.in/@huquqiy_axborot/H1cM2c-VV instituti

15. http://uzmarkaz.uz/uzc/news/mediatsiya-nizolarni-hal-etishning-muqobil- 